\title{
A faunal survey of the Dieng Mountains, Central Java, Indonesia: distribution and conservation of endemic primate taxa
}

\author{
Vincent Nijman and S. (Bas) van Balen
}

\begin{abstract}
A faunal survey was conducted in May-September 1994 and June-July 1995 in the Dieng Mountains, one of the last remaining larger patches of forest in Central Java province, Indonesia. All three primate species endemic to the Javan faunal region - Javan gibbon Hylobates moloch, grizzled leaf monkey Presbytis comata and ebony leaf monkey Trachypithecus auratus - were found to be present. Hylobates moloch occurs only in the lowland and hill forests in the western part of the study area, while the other two species were found throughout the area from lowland to montane forests. Although more research needs to be done on habitat preferences and densities at which the primates occur, the available data suggest that the Dieng Mountains may harbour the second largest populations of both $\mathrm{H}$. moloch and $\mathrm{P}$. comata in the same location. In order to safeguard these two endangered primates it is suggested that the reserve system in Java be expanded to include the Dieng Mountains.
\end{abstract}

\section{Introduction}

Despite Central Java being one of the most densely populated and most deforested areas in Indonesia, several patches of natural forest remain throughout the province. This natural vegetation is restricted almost exclusively to hydrological forest reserves capping summits and ridges. A few of these forests descend into the hill or even lowland zone, but more often they only cover the upper part of the mountains above $1500-2000 \mathrm{~m}$. Few of these patches are adequately protected and fewer still have received recent attention from the conservation community. It has long been known that several 'West Javan' species with high conservation priorities reach the easternmost limit of their distributions in Central Java but most conservation efforts or even general survey work seem to be restricted to West Java (see, e.g. Appendix II and III in Whitten et al., 1996).

Given the lack of knowledge on the current distribution and status of several animal species in Central Java, we present results of a faunal survey in the largest remaining area of natural forest in Central Java, the Dieng Mountains (also known as Mt Prahu or Mt Perahu, after the highest peak; Figure 1).

Between May 1994 and July 1995 six visits were paid to the forest area of the Dieng Mountains. The aim of the visits was to obtain data on the bird and mammal fauna of the region in order to make recommendations for the conservation of the area.

The subject of this paper is to discuss three primate taxa found in the area: Javan or silvery gibbon Hylobates moloch, grizzled leaf monkey Presbytis comata and ebony leaf monkey Trachypithecus auratus.

The Javan gibbon is endemic to the western half of Java. Most populations can be found in the western province (Kappeler, 1984), but a few remain in Central Java (Nijman, 1995; Nijman and Sözer, 1995). The most recent population estimates, based on extrapolation of the available habitat, range from 2000 animals (Supriatna et al., 1994) to 3000 animals (Asquith et al., 1995). The species is accorded the highest conservation priority rating for 


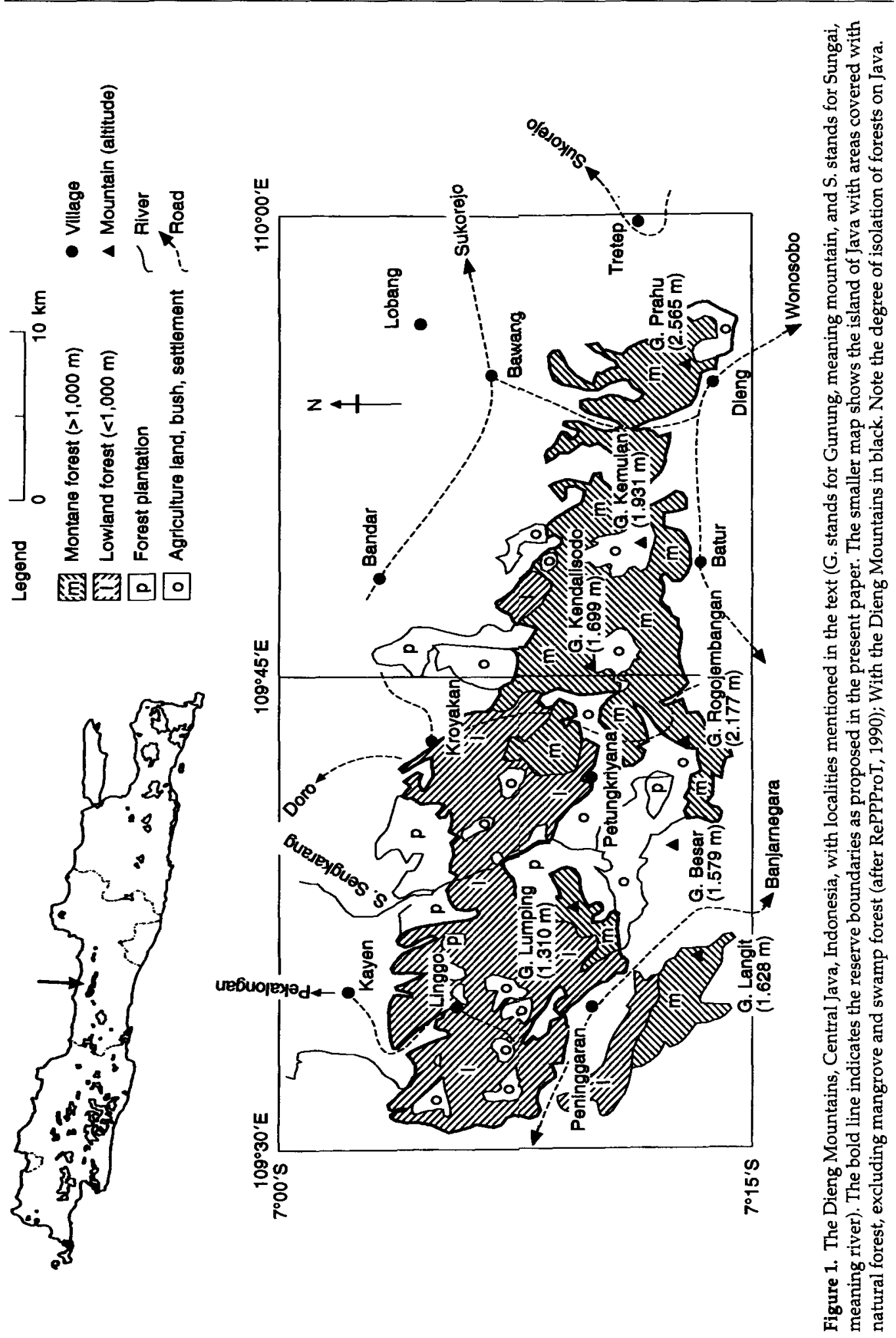




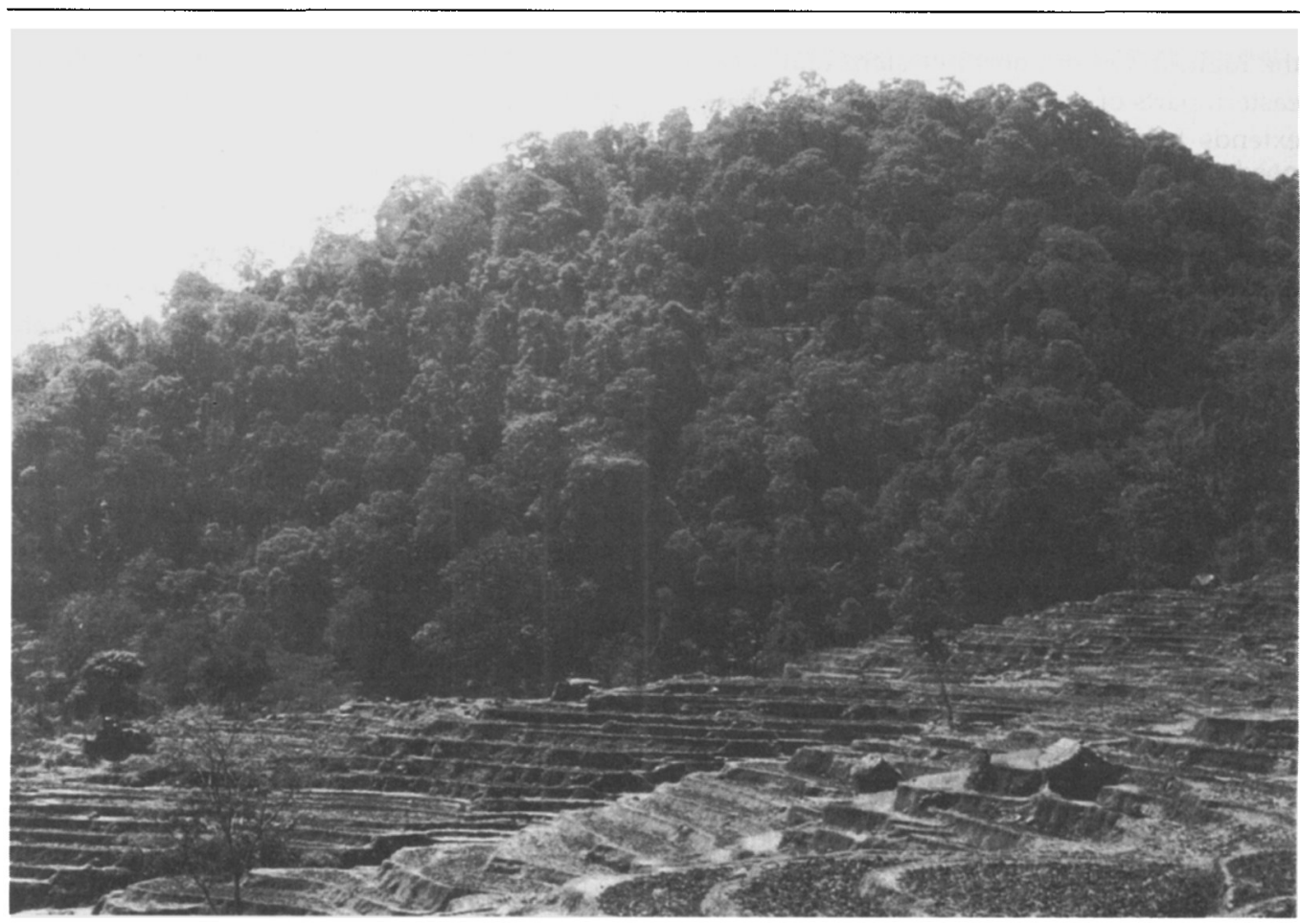

The Dieng Mountains, Central Java. A view of the lowland forests near Linggo, with areas cleared for wet rice fields in the foreground (V. Nijman).

Asian primates (Eudey, 1987), and has recently been listed as Critically Endangered by IUCN (1996).

The grizzled leaf monkey is also endemic to the western half of Java, as far as Mt Lawu on the border with East Java (Nijman, 1997b). The central Javan populations have been proposed as a separate species Presbytis fredericae (e.g. Brandon-Jones, 1995), but Nijman (1997a) showed some of the alleged differences not to be diagnostic, while some intraspecific variation was of a clinal nature. Like the Javan gibbon, the species is severely threatened mainly due to habitat destruction (Eudey, 1987; MacKinnon, 1987; Supriatna et al., 1994). Population sizes have been calculated and range from 8040 animals (MacKinnon, 1987) to 2285 animals (Supriatna et al., 1994). Grizzled leaf monkeys have been classified as Endangered according to IUCN (1996).

The ebony leaf monkey is more widespread than the former species, and is restricted to Java and the smaller islands of Bali and
Lombok to the east (Weitzel and Groves, 1985). The species is listed as Vulnerable (IUCN, 1996).

\section{Methods}

\section{Study site}

The Dieng Mountains are situated in the middle of Central Java, between c. $109^{\circ} 32^{\prime}$ $109^{\circ} 56^{\prime} \mathrm{E}$ and $7^{\circ} 04^{\prime}-7^{\circ} 13^{\prime} \mathrm{S}$. Administratively they lie largely in the counties (kabupaten) of Pekalongan and Batang, with small areas in Banjarnegara, Wonosobo, Temanggung and Kendal. The area is made up of a number of largely dormant volcanoes, which are more or less contiguous, surrounded by foothills and adjoining plains. In the western part most peaks are less than $2000 \mathrm{~m}$ high (e.g. Mt Langit, $1628 \mathrm{~m}$; Mt Besar, $1579 \mathrm{~m}$ ), while to the east the mountains become gradually higher. Mt Prahu in the easternmost part is, at $2565 \mathrm{~m}$, 
the highest. On the north-western and northeastern parts of these mountains a forest block extends from lowland to upper montane: in the west the forest descends to $c .300 \mathrm{~m}$ and on the eastern slopes of Mt Prahu to c. $1500 \mathrm{~m}$. Forests cover c. $255 \mathrm{sq} \mathrm{km} \mathrm{(RePPProT,} \mathrm{1990),}$ disregarding the additional area due to slopes. The archaeologically well known Dieng Plateau, situated at an altitude of c. $2000 \mathrm{~m}$, borders the area in the south-east and contains some interesting lakes, which are gazetted as nature reserves: Telogo Warna (40 ha), Telogo Dringo (26 ha) and Telogo Sumurup (20 ha) (MacKinnon et al., 1982).

Rainfall is plentiful throughout the year with an average of $4000-7000 \mathrm{~mm}$; only between June and September is there a little less rainfall. In most of the study area more than 40 rainy days are recorded during the 4 driest consecutive months of the year (van Steenis, 1965). In the lowlands the average daily temperature is $22-34^{\circ} \mathrm{C}$ with an average of $26^{\circ} \mathrm{C}$. Temperature decreases with altitude; at $2000 \mathrm{~m}$ average daily temperature is $14^{\circ} \mathrm{C}$ (van Steenis, 1972). On the Dieng Plateau, and other areas above $2000 \mathrm{~m}$, frost can occur at night, especially in the dry season.

The vegetation of the Dieng Mountains is of the wettest type: mixed lowland and hill rain forest, below $c .1000 \mathrm{~m}$, and montane ever-wet rain forest to c. $2400 \mathrm{~m}$ (van Steenis, 1972). As a result of human disturbance and/or natural conditions, meadows with few trees cover the upper parts of Mt Prahu. Throughout the area some large patches of undisturbed primary forest remain, but most of the area is somewhat disturbed. The forests near the village of Linggo partly consist of a former coffee plantation which, according to local inhabitants, was abandoned in the 1930s. Halfway between Linggo and Mt Lumping small patches of bamboo indicate a former settlement. Regrowth has resulted in secondary forest, with emergent older trees distributed throughout. In the central part of the area, along the road from Kroyakan to the Dieng Plateau, and in the north-west, wet rice fields are present.

The forests on the Dieng Mountains are not yet protected as conservation forest. The parts above $1000 \mathrm{~m}$ are formally protected as hutan lindung (protection forest). Forests protected in this category are state-owned and serve as water catchments, to maintain soil fertility and to prevent erosion and land slides (Anon., 1996). Also a small part of the lowland forests near Kroyakan receives protection as hutan negara (an unclassified state-owned forest category); here collection of fire wood and forest products is prohibited. The lowland forest near Linggo is managed as hutan produksi (production forest) and in 1995 there were still plans to convert it into rubber and/or pine plantations. The forests on Mt Prahu above $1000 \mathrm{~m}$, i.e. roughly the eastern half of the Dieng Mountains, have been proposed as a suaka margasatwa (wildlife sanctuary) (MacKinnon et al., 1982).

The study area is largely surrounded by tea plantations in the north and south, by pine plantations in the east and west, by rubber plantations in the north-west, and by agricultural land in the south-east. It is crossed by at least three roads running from north to south: from Kayen via Linggo to Peninggaran, from Kroyakan to Batur and the Dieng Plateau, and from Bawang to Dieng. The latter two are used only for local traffic.

\section{Data acquisition and survey methods}

We surveyed the Dieng Mountains on six occasions totalling 16 days of observation: (i) on 5 May 1994 VN and Resit Sözer (RS), visited the northern part of Mt Prahu from the village of Bawang; (ii) on 4-6 July $1994 \mathrm{VN}$ and RS visited Dieng Plateau and the southern slopes of Mt Prahu; (iii) VN, RS, Iwan Setiawan (IS) and Andi Prima Setiadi (APS) surveyed the eastern slopes of Mt Prahu from Tretep on 26 August 1994 and the forests near Linggo on 27 August 1994; (iv) on 25 September 1994 VN surveyed the forests near Linggo; (v) on 9-11 June $1995 \mathrm{VN}$ and SvB visited the Dieng Plateau and the southern slopes of Mt Prahu; and on 11-16 June 1995 the surroundings of Linggo, including a 2-day visit to $\mathrm{Mt}$ Lumping; and (vi) on 29 July $1995 \mathrm{VN}$ travelled along the road from near Batur to Kroyakan, with short surveys inside the forest 
on the north side of Mt Rogojembangan and near Kroyakan. The survey covered almost the total altitudinal range from $300-2565 \mathrm{~m}$, with only a small gap at $1800-2000 \mathrm{~m}$. We spent almost equivalent amounts of time in the lowland and hill forest below $1000 \mathrm{~m}$ as in the montane and upper montane forests above $1000 \mathrm{~m}$.

The primate surveys were as much as possible concentrated in the interior of the forest areas and focused on the three endemic primate taxa: Hylobates moloch, Presbytis comata and Trachypithecus auratus. According to local informants the long-tailed macaque Macaca fascicularis was also present as might be the slow loris Nycticebus coucang, but hese two species were not recorded during the survey.

The area was surveyed from vantage points over the canopy and by walking inside the forest along available trails. The presence of gibbons was established mainly by their calls. Gibbon density in the forests between Linggo and Mt Lumping, covering an area of $c .11 \mathrm{sq}$ $\mathrm{km}$ between altitudes of $c .300-1300 \mathrm{~m}$, was estimated by plotting the locations of gibbon song bouts heard from fixed points and while surveying on a map. In the same area a transect of $3.8 \mathrm{~km}$ in length, partially along an existing trail, was walked using a fixed strip width of $100 \mathrm{~m}$, and was repeated four times, thus covering an area of $1.52 \mathrm{sq} \mathrm{km}$. This allowed density estimates to be made for the two leaf monkeys. Whenever a primate or group of primates was encountered observations were made ad libitum (Altmann, 1974), and data on the habitat were collected. Ad libitum sampling is not to be recommended for long-term comprehensive studies but can be useful during preliminary observations (Martin and Bateson, 1993). Ad libitum sampling was used by default because there were no established trail systems in the area, the study covered a relatively short time span, the study animals were not habituated, and observation conditions were relatively difficult.

Additional information on the presence or absence of primate species was gathered by interviewing local inhabitants, collectors of forest products (e.g. coffee and rattan) and officers of the forestry department.

\section{Brief historical account of former faunal exploration}

Relatively little faunal exploration has been done in the study area other than on the Dieng Plateau itself. Some botanists, such as S. H. Koorders (October, 1891), C. A. Backer (January 1917; see Bünnemeyer, 1918) and C. G. G. J. van Steenis (August, 1930) collected on the Dieng Plateau and Mt Prahu (van SteenisKruzeman, 1950). The naturalist Junghuhn (1854) visited the Dieng Plateau and Mt Prahu (March-April 1840, October-November 1845). The interior and the western parts of the study area have always been somewhat neglected. The only zoologist who contributed considerably to the knowledge of the area is Thomas Horsfield who, in October 1816, collected some birds and mammals, some of which are type specimens (Horsfield, 1824; Mees, 1989).

Bartels (1937) reported on a series of Presbytis comata skins collected at an altitude of $c$. 1300-1500 m, which he received from $\mathrm{Mr}$ Landberg, owner of a plantation on the northwestern slopes of the Dieng Mountains. Apart from Kappeler (1984), who visited Mt Prahu in 1978 during a gibbon survey, other primatologists, such as Asquith et al. (1995), Martarinza (pers. comm. 1994) and M. Linsley (pers. comm. 1994), did not survey the Dieng Mountains. Kappeler (1984) did not find forest below $2100 \mathrm{~m}$ on Mt Prahu, and did not find any gibbons.

As a result of the insufficient coverage by naturalists, the forest on the Dieng Mountains was for a long time considered to be of only minor significance for the preservation of Javan biological diversity. The area was accorded the lowest overall priority ranking by MacKinnon et al. (1982), although the area was stated to be an important water catchment and of some botanical and faunal interest'.

\section{Results}

Primate distribution and habitat preferences

Javan gibbons were found to be present between altitudes of $c .300$ and $1300 \mathrm{~m}$ from 
Linggo and Mt Lumping in the west to $\mathrm{Mt}$ Rogojembangan in the south-east (Table 1). Gibbon habitat consisted of secondary forest with a rather dense and close canopy, and undisturbed primary forest. The detected gibbons all appeared to prefer the taller trees for resting, foraging and locomotion. Gibbons were seen on three occasions: a single adult, two adults and a group of seven. On the basis of simultaneous or alternating vocalizations and sightings a total of 10-12 groups could be recognized in an area of $c .11 \mathrm{sq} \mathrm{km}$ between Linggo and Mt Lumping. Assuming an average group size of 3.3 individuals (cf. Kappeler, 1984) the density of gibbons was estimated to be $3.0-3.6$ individuals per sq $\mathrm{km}$. Two

Table 1. Groups or individuals of Javan gibbon Hylobates moloch, grizzled leaf monkey Prebytis comata and ebony leaf monkey Trachypithecus auratus observed in the Dieng Mountains

\begin{tabular}{|c|c|c|c|c|c|}
\hline Species & Date & $\begin{array}{l}\text { No. groups } \\
\text { heard }\end{array}$ & $\begin{array}{l}\text { No. individuals } \\
\text { seen }\end{array}$ & $\begin{array}{l}\text { Altitude } \\
\text { (m) }\end{array}$ & Locality \\
\hline \multirow[t]{12}{*}{ H. moloch } & $27 / 08 / 94$ & 2 & - & c. $400-600$ & Linggo \\
\hline & & & 1 & 600 & Linggo \\
\hline & $25 / 09 / 94$ & 2 & - & c. $400-600$ & Linggo \\
\hline & & 1 & - & c. 750 & Linggo (central)* \\
\hline & $11-14,16 / 06 / 95$ & $3-4$ & - & c. $300-700$ & Linggo \\
\hline & $12 / 06 / 95$ & - & 2 & 765 & Linggo \\
\hline & $13 / 06 / 95$ & 1 & - & 880 & Linggo (central) \\
\hline & & 1 & 7 & 885 & Linggo (central) \\
\hline & $14 / 06 / 95$ & 2 & - & c. $850-900$ & Linggo (central) \\
\hline & $14-15 / 06 / 95$ & $5-6$ & - & c. $1000-1300$ & Mt Lumping \\
\hline & 29/07/95 & 1 & - & c. 1200 & Mt Rogojembangan \\
\hline & & 1 & - & c. 700 & Kroyakan \\
\hline \multirow[t]{11}{*}{ P. comata } & $05 / 07 / 94$ & - & 2 & 2565 & Mt Prahu \\
\hline & $11 / 06 / 95$ & 1 & - & 2500 & Mt Prahut \\
\hline & $13 / 06 / 95$ & - & 11 (+ 2 neonates) & 780 & Linggo \\
\hline & & - & 9 (+ 1 neonate) & 820 & Linggo \\
\hline & & - & 2 & 820 & Linggo \\
\hline & & - & $>1$ & 650 & Linggo \\
\hline & $14 / 06 / 95$ & - & $>4$ & 925 & Linggo (central) \\
\hline & & 1 & - & 1085 & Mt Lumping \\
\hline & & 1 & - & 1150 & Mt Lumping \\
\hline & $15 / 06 / 95$ & - & $>2$ & 820 & Linggo \\
\hline & & - & 7 & 775 & Linggo \\
\hline \multirow[t]{12}{*}{ T. auratus } & $25 / 09 / 94$ & - & $>3$ & $750-800$ & Linggo \\
\hline & & - & $>4$ & $750-800$ & Linggo \\
\hline & & - & 7 (+1 neonate) & 850 & Linggo (central) \\
\hline & $12 / 06 / 95$ & _- & 3 & 765 & Linggo \\
\hline & & - & 15 (+ 4 neonates) & 780 & Linggo \\
\hline & & - & $10-12(+1$ neonate $)$ & 815 & Linggo \\
\hline & $14 / 06 / 95$ & 1 & - & 1300 & Mt Lumping \\
\hline & $15 / 06 / 95$ & - & 1 & 865 & Linggo (central) \\
\hline & & _- & $8-10$ & 800 & Linggo (central) \\
\hline & $16 / 06 / 95$ & - & $>5$ & 570 & Linggo (north)* \\
\hline & & 1 & - & 600 & Linggo (north) \\
\hline & & 1 & - & 500 & Kroyakan \\
\hline
\end{tabular}

* Linggo (central) refers to the area between Linggo and Mt Lumping, Linggo (north) refers to the lowland forests north of Linggo. See Figure 1.

t Unconfirmed, see text. 
additional groups were found on the northern slopes of $\mathrm{Mt}$ Rogojembangan and near Kroyakan, respectively.

Grizzled leaf monkeys were found both in the western part of the study area and on the higher parts of Mt Prahu (Table 1). In July 1994 two individuals were observed near the summit of Mt Prahu (Nijman and Sözer, 1995) and on 11 June 1995 a troop of monkeys were detected near the same place. However, because of the dense cover and the angle of observation it was not clear whether these individuals were grizzled leaf monkeys or ebony leaf monkeys.

More direct observations were made in the western part of the study area. Groups of 2-13 individuals were seen on seven occasions. The smaller group sizes were probably a reflection of the difficulties in observing the complete group rather than the size of the group itself. On three occasions we had the impression that we could observe the whole troop, with group sizes of at least seven individuals, nine plus one neonate, and eleven plus two neonates. Two groups were detected by means of their characteristic vocalizations. In total at least six different groups inhabited the study area.

On six occasions we observed a group of grizzled leaf monkeys within $50 \mathrm{~m}$ from the transect line. Assuming an average group size of seven individuals (cf. Supriatna et al., 1994) the population density was estimated at 28 individuals per sq $\mathrm{km}$. We observed the species between 650 and $2565 \mathrm{~m}$. Local inhabitants and officers of the forestry department reported it to be present north of Linggo (forest descends to $c .300 \mathrm{~m}$ ) and also in the forests above Kroyakan (c. $400 \mathrm{~m}$ ). Grizzled leaf monkeys were recorded in primary forest and in secondary forest, both at the edges and in the interior. They were found in lowland forests, in forests on steep slopes and on hills, and in upper montane forests.

The ebony leaf monkey was the species observed most frequently. It was reported to be rather common on both Mt Prahu and the central part of the study area. In the western part we sighted groups on nine occasions and twice located group or individuals by their characteristic vocalizations. In the forests above Kroyakan a group was also identified by means of its calls. Records come from the north-western part, north of Linggo, to Mt Lumping in the south and Kroyakan in the north-east, between altitudes of 500 and $1300 \mathrm{~m}$ (Table 1). At least eight groups of 3-19 individuals of ebony leaf monkey were present in the study area. Along the transect line a group was observed five times. Assuming an average group size of seven individuals (V. Nijman, unpubl. data) the density may be 23 individuals per sq $\mathrm{km}$. The habitat in which ebony leaf monkeys were observed included primary and secondary forest, both on the edges and in the interior.

\section{Population estimates}

Although preliminary, we present some information on the number of individuals of the two most endangered primate species - the Javan gibbon and the grizzled leaf monkey possibly present within the area. The Javan gibbon was observed between altitudes of $c$. 300 and $1300 \mathrm{~m}$. It is likely to be distributed throughout the western half of the study area up to altitudes of $c .1600 \mathrm{~m}$. This is considered to be the species's upper limit (Kappeler, 1984), although it has been reported from higher altitudes (e.g. $2400 \mathrm{~m}$ on Mt Pangrango: Doctors van Leeuwen, 1926; 1900 m on Mt Tangkuban Perahu: R. Sözer, pers. comm., 1992). The most widely used method for estimating population sizes of Javan gibbons is by extrapolation based on the forest area inhabited by gibbons and their population density (e.g. Kappeler, 1984; Kool, 1992; Supriatna et al., 1994; Asquith et al., 1995). Population densities vary with altitude (Kappeler, 1984; Supriatna et al., 1994) and we followed the assumptions of Supriatna $e t$ al. (1994), which are comparable with those of Kappeler (1984) and Asquith et al. (1995). The assumptions of Supriatna et al. (1994) are based on data derived from studies of the white handed $(H$. lar) and pileated gibbon $(H$. pileatus). They considered the edge effect (defined as the size of habitat on the forest periphery not occupied by gibbons) for Javan gibbons to be $1 \mathrm{~km}$. Thus, suitable habitat for 
Table 2. Estimates of the numbers of Javan gibbon present in different vegetation zones on Dieng Mountains and total number of gibbons present in the area

\begin{tabular}{lllllc}
\hline $\begin{array}{l}\text { Altitudinal } \\
\text { vegetation zone }(\mathrm{m})\end{array}$ & $\begin{array}{l}\text { Size } \\
(\mathrm{sq} \mathrm{km})\end{array}$ & $\begin{array}{l}\text { Edge }^{*} \\
(\mathrm{sq} \mathrm{km})\end{array}$ & $\begin{array}{l}\text { Core* } \\
(\mathrm{sq} \mathrm{km})\end{array}$ & $\begin{array}{l}\text { Densityt } \\
\text { (individuals/sq km) }\end{array}$ & $\begin{array}{l}\text { Estimated } \\
\text { number }\end{array}$ \\
\hline Lowland (0-500) & $13-15$ & $6-7$ & $7-8$ & $1-3$ & $7-24$ \\
Hill (500-1000) & $90-100$ & $20-23$ & $70-77$ & 7 & $490-539$ \\
Lower montane (1000-1500) & $17-20$ & $6-8$ & $11-12$ & 2 & $22-24$ \\
Montane (1500-2565) & $120-135$ & -- & - & - & -- \\
Total & c. 255 & & & & $519-577$
\end{tabular}

* Size of natural forest area after RePPProT (1990), scale 1:250,000; edge is defined as the first km of habitat on the forest periphery not occupied by gibbons, while core is calculated by subtracting the area of the edge from the forest size (after Supriatna et al., 1994).

† Densities after Supriatna et al. (1994).

gibbons was calculated by subtracting the first kilometre of habitat from the available habitat. This area was multiplied by the gibbon population density for that altitudinal vegetation zone (Table 2). A population of over 500 individuals may be present in the area.

Less is known about densities and altitudinal distribution of grizzled leaf monkeys than for the Javan gibbon. Reported densities vary from 4-5 individuals per sq $\mathrm{km}$ in Halimun National Park (Maitar in Supriatna et al., 1994) to 35 individuals per sq $\mathrm{km}$ in Patenggang (Ruhiyat, 1983). Our density estimate of 28 individuals per $\mathrm{sq} \mathrm{km}$ is similar to the 25 individuals per sq $\mathrm{km}$ found by Sujatnika (1992; Sujatnika, pers. comm.) in Mts Gede Pangrango National Park. According to Supriatna et al. (1994), grizzled leaf monkeys do not inhabit the core of a forested area. Although tentative, if we, for reason of comparison only, follow the assumptions of Supriatna et al. (1994), i.e. grizzled leaf monkeys range in a band of $2 \mathrm{~km}$ around the perimeter of the area with a density of five individuals per sq $\mathrm{km}$, the available habitat totals $c .140-155 \mathrm{sq} \mathrm{km}$ and the total number of grizzled leaf monkeys present in the Dieng Mountains may be $c$. 700-800 animals.

Table 3. Estimates of the numbers of Javan gibbon present in different vegetation zones on Dieng Mountains using the assumptions of Kappeler (1984) and Asquith et al. (1995)

\begin{tabular}{|c|c|c|c|}
\hline $\begin{array}{l}\text { Altitudinal } \\
\text { vegetation zone }(\mathrm{m})\end{array}$ & $\begin{array}{l}\text { Size* } \\
(\mathrm{sq} \mathrm{km})\end{array}$ & $\begin{array}{l}\text { Density }{ }^{+} \\
\text {(individuals } / \mathrm{sq} \mathrm{km} \text { ) }\end{array}$ & $\begin{array}{l}\text { Estimated } \\
\text { number }\end{array}$ \\
\hline \multicolumn{4}{|l|}{ After Kappeler (1984) } \\
\hline Lowland $(0-500)$ & $13-15$ & $4-13$ & $52-195$ \\
\hline Hill $(500-1000)$ & $90-100$ & $2-7$ & $180-700$ \\
\hline Lower montane (1000-1500) & $17-20$ & $1-3$ & $17-60$ \\
\hline Total & $120-135$ & & 249-955 \\
\hline \multicolumn{4}{|l|}{ After Asquith et al. (1995) } \\
\hline $0-1000 \mathrm{~m}$ & $77-85$ & 6.5 & $501-553$ \\
\hline $1000-2000 \mathrm{~m}$ (western part only) & $11-12$ & 2 & $22-24$ \\
\hline Total & $88-97$ & & $523-577$ \\
\hline
\end{tabular}

* Size of natural forest area after RePPProT (1990), scale 1:250,000.

t Note that Asquith et al. (1995) took the edge effect into account but that Kappeler (1984) did not. 


\section{Discussion}

Even though we realize that some of our data are rather limited and based on few observations, we think that they allow comparison with other studies. Supriatna et al. (1994) concluded that there was an inconsistent and incomplete data set available to estimate the sizes of wild gibbon and leaf monkey populations. In our attempts to estimate the number of Javan gibbons and grizzled leaf monkeys present in the Dieng Mountains, we largely followed the assumptions of Supriatna et al. (1994). Some of these assumptions, however, are considered not to be valid in our study area, e.g. gibbons were heard frequently less than $100 \mathrm{~m}$ from the main road from Kayen to Peninggaran, and they were reported to be present in the lowland forest south-west of the road from Kroyakan to Doro, questioning the assumption that gibbons do not inhabit the first kilometre of the forest periphery. If we use the assumptions and densities estimated by Kappeler (1984) and Asquith et al. (1995) to estimate the number of gibbons in the Dieng Mountains, the results are similar to our own: 249-955 and 523-577, respectively (see Table 3 ).

Furthermore, we do not agree with the assumption of Supriatna et al. (1994) that grizzled leaf monkeys are not found in the core of a forested area, and a density of five individuals sq $\mathrm{km}$ seems rather conservative because our own estimate and those reported from other studies (e.g. Ruhiyat, 1983; Sujatnika, 1992) are considerably higher. However, pending further research on the population density and habitat preferences of grizzled leaf monkeys, any further adjustment seems unwarranted.

Despite the number of limitations and perhaps low level of accuracy we have presented our population estimates because we believe that (i) even these rough estimates are useful in order to gain some idea of population sizes and (ii) the estimates allow comparison with other areas and other studies that have been conducted so far.

The only area, other than the Dieng Mountains, where both grizzled leaf monkey and Javan gibbon are present in greater or similar numbers is Halimun National Park in West Java $(360 \mathrm{sq} \mathrm{km}$ of forest between 500 and $1929 \mathrm{~m}$, of which 80 per cent is above 1200 $\mathrm{m}$; Kool, 1992). Most patches of strict lowland forest in Halimun National Park are discontinuous and are often situated outside the reserve boundaries (Whitten et al., 1996), so while the area's protected status might create the illusion that populations of Javan gibbons and grizzled leaf monkeys are relatively secure, this is not necessarily the case. Population estimates of Javan gibbon for this area range from 852-1320 animals (Kool, 1992), 870 animals (Asquith et al., 1995) to 908 animals (Supriatna et al., 1994). Up to 720 grizzled leaf monkeys may be present (Supriatna et al., 1994) although Maitar (in Supriatna et al., 1994) reports very low densities of this species in the area and Kool (1992) was not able to obtain a density estimate because of the low number of sightings.

During our surveys in the Dieng Mountains we were repeatedly confronted with the fact that no one had recognized the high conservation value of this area before. Therefore, and as our surveys were limited in time and did not cover the area as a whole, we highly recommend the area for those interested in studying Javan fauna and flora in more detail. In our survey, for instance, we observed or found traces of species such as large flying fox Pteropus vampyrus, binturong Arctictus binturong, leopard Panthera pardus, pigs Sus scrofa and/or S. verrucosus, barking deer Muntiacus muntjak and black giant squirrel Ratufa bicolor. There must still be much to discover. Scientific research would not only provide new information and better insight, but would also serve as a constant reminder of the conservation importance of the Dieng Mountains.

Contrary to MacKinnon (1987), we strongly believe that there is room for a further expansion of the reserve system on Java. In Central Java, currently scarcely any large terrestrial area has an adequate protected status, although several have been proposed as nature reserves or wildlife sanctuaries (MacKinnon et al., 1982). As conversion of the last remaining natural forest areas on Java is an ongoing 
Box 1. Endemic and Restricted Range (RR) bird species recorded in the Dieng Mountains

\begin{tabular}{|c|c|c|c|}
\hline English name & Scientific name & Endemic $^{*}$ & RRt \\
\hline Javan hawk-eagle & Spizaetus bartelsi & - & $\bullet$ \\
\hline Chestnut-bellied partridge & Arborophila javanica & - & - \\
\hline Pink-headed fruit-dove & Ptilinopus porphyreus & & $\bullet$ \\
\hline Yellow-throated hanging-parrot & Loriculus pusillus & - & \\
\hline Javan kingfisher & Halcyon cyanoventris & - & $\bullet$ \\
\hline Brown-throated barbet & Megalaima corvina & - & - \\
\hline Black-banded barbet & Megalaima javensis & - & \\
\hline Orange-fronted barbet & Megalaima armillaris & - & - \\
\hline Sunda minivet & Pericrocotus miniatus & & $\bullet$ \\
\hline Orange-spotted bulbul & Pycnonotus bimaculatus & & - \\
\hline Sunda streaked bulbul & Hypsipetes viriscens & & $\bullet$ \\
\hline Sunda blue robin & Cinclidium diana & & $\bullet$ \\
\hline White-breasted babbler & Stachyris grammiceps & - & - \\
\hline White-bibbed babbler & Stachyris thoracica & $\bullet$ & $\bullet$ \\
\hline Crescent-chested babbler & Stachyris melanothorax & - & - \\
\hline Grey-cheeked tit-babbler & Macronous flavicollis & $\bullet$ & $\bullet$ \\
\hline Javan fulvetta & Alcippe pyrrhoptera & - & - \\
\hline Javan tesia & Tesia superciliaris & $\bullet$ & $\bullet$ \\
\hline White-rumped warbler & Seicercus grammiceps & & - \\
\hline Rufous-tailed fantail & Rhipidura phoenicura & - & $\bullet$ \\
\hline White-bellied fantail & Rhipidura euryura & $\bullet$ & - \\
\hline Pygmy tit & Psaltria exilis & $\bullet$ & - \\
\hline White-flanked sunbird & Aethopyga eximia & $\bullet$ & - \\
\hline Violet-tailed sunbird & Aethopyga mystacalis & $\bullet$ & \\
\hline Grey-throated darkeye & Lophozosterops javanicus & - & $\bullet$ \\
\hline Sunda serin & Serinus estherae & & - \\
\hline
\end{tabular}

* Endemic is defined as being restricted to the Javan faunal region, i.e. the islands of Java and Bali.

+ Restricted Range species is one that has a breeding range of less than 50,000 sq km (Bibby et al., 1992; Sujatnika et al., 1995).

Nomenclature and sequence follow Andrew (1992).

process, resulting in ever increasing fragmentation, it is of utmost importance to raise one or preferably more areas in the central part of the island to a higher conservation status.

The Dieng Mountains support relatively high numbers of two of Indonesia's most threatened primate species, the Javan gibbon and the grizzled leaf monkey, making it a top priority area for primate conservation. The area is among the most diverse left on Java, notably being one of the few unprotected forests that covers the whole range from lowland to upper montane. It harbours 67 per cent of all bird species endemic to Java and Bali (20 of 30 species), and 70 per cent of the Javan Restricted Range forest birds (23 of 33 species; see Box 1). The creation of a reserve in the Dieng Mountains would be of international importance for global biological diversity conservation. The area is probably sufficiently large to ensure the maintenance of viable populations of unique flora and fauna.

Following Nijman and Sözer (1996) we suggested that the proposed wildlife sanctuary (MacKinnon et al., 1982) be extended to the north-west so as to include the lowland and lower montane forest of Linggo. In the central area, the boundary should follow the line between the summits of $\mathrm{Mt}$ Rogojembangan and Mt Kendalisodo. From Mt Kendalisodo the boundary should run westwards - excluding the village of Petungkriyana-up to the Sengkarang River. From there the boundary should follow the eastern and southern slopes of Mt Lumping. We recommended that the provincial or national authorities assessed the 
feasibility of creating a nature reserve or national park in the Dieng Mountains. If the reserve is to become a national park consideration should be given whether or not to include the Dieng Plateau, with the three established lake nature reserves.

The results of the present survey, and the proposals to extend the proposed wildlife sanctuary into the lowland zone, have been well received by the Directorate General of Forest Protection and Nature Conservation (PHPA), and currently gazettement is being processed.

\section{Acknowledgements}

We thank the Indonesian Institute for Science (LIPI) for sponsoring our research and the Directorate General of Forest Protection and Nature Conservation (PHPA) for allowing us to conduct our fieldwork. BirdLife International Indonesia Programme is thanked for its support and especially the co-operation of Paul Jepson and Sujatnika is acknowledged. Sujatnika helped with preparing the map. Resit Sözer is thanked for his work during parts of the 1994 surveys, as are Iwan Setiawan and Andi Prima Setiadi. Drs Boeadi (Museum Zoologi Bogor) helped with identification of prey remains. Dr H. Albrecht, Dr P.J.H. van Bree, Dr J. Chapman and three referees commented on earlier drafts.

\section{References}

Altmann, J. 1974. Observational study of behavior: sampling methods. Behaviour, 49, 227-267.

Andrew, P. 1992. The Birds of Indonesia - A Checklist (Peters' sequence). Indonesian Ornithological Society, Jakarta.

Anon. 1996. Pola pengelolaan kawasan suaka alam, kawasan pelestarian alam, taman buru, dan hutan lindung. Dirjen PHPA/Forestry Department, Jakarta. [In Indonesian.]

Asquith, N.M., Martarinza and Sinaga, R.M. 1995. The Javan gibbon (Hylobates moloch): status and conservation recommendations. Tropical Biodiversity, 3, 1-14.

Bartels, M. 1937. Zur Kenntnis der Verbreitung und der Lebensweise javanischer Säugetiere. Treubia, 16, 149-164. [In German.]

Bibby, C.J., Collar, N.J., Crosby, M.J. Heath, M.F., Imboden, Ch., Johnson, T.H., Long, A.J, Stattersfield, A.J. and Thirgood, S.J. 1992. Putting Biodiversity on the Map: Priority Areas for Global Conservation. International Council for Bird
Preservation, Cambridge, UK.

Brandon-Jones, D. 1995. Presbytis fredericae (Sody, 1930), and endangered Colobine species endemic to Central Java, Indonesia. Primate Conservation, $16,68-70$.

Bünnemeyer, H.A.B. 1918. Een tocht naar het Diëngplateau (20-29 januari, 1917). Tropische Natuur, 8, 43-48/69-74/101-104/122-124/135-138. [In Dutch.]

Docters van Leeuwen, W. 1926. Uit het leven van planten en dieren op de top van de Pangeango. IIIa De dieren. Tropische Natuur, 15, 57-65. [In Dutch.]

Eudey, A.A. 1987. Action Plan for Asian Primate Conservation: 1987-1991. IUCN/SSC Primate Specialist Group, Gland, Switzerland.

Horsfield, T. 1824. Zoological Researches in Java, and the Neighbouring Islands. Kingsbury, Parbury and Allen, London.

IUCN 1996. 1996 IUCN Red List of Threatened Animals. IUCN, Gland, Switzerland.

Junghuhn, F. 1854. Java zijn gedaante, zijn plantentooi en zijn inwendige bouw. Deel 2. 2nd edn. C.W. Mieling, 's Gravenhage. [In Dutch.]

Kappeler, M. 1984. The gibbon in Java. In The Lesser Apes: Evolutionary and Behavioural Biology (eds L. Preuschoft, D. Chivers, W. Y. Brockelman and N. Creel), pp. 19-31. Edinburgh University Press.

Kool, K. 1992. The status of endangered primates in Gunung Halimun reserve, Indonesia. Oryx, 26, 29-33.

MacKinnon, K. 1987. Conservation status of primates in Malaysia with special reference to Indonesia. Primate Conservation, 8, 175-183.

MacKinnon, J., Smiet, F. and Artha, M.B. 1982. A National Conservation Plan for Indonesia, Vol Ill: Java and Bali. Food and Agricultural Organization of the United Nations, Bogor.

Martin, P.H. and Bateson, P.P.G. 1993. Measuring Behaviour. An Introductory Guide. 2nd edn. Cambridge University Press, Cambridge.

Mees, G.F. 1989. Remarks on the ornithological parts of Horsfield's 'Zoological researches in Java'. Proceedings van de Koninklijke Nederlandse Academie van Wetenschappen C, 92, 367-378.

Nijman, V. 1995. Remarks on the occurrence of gibbons in Central Java. Primate Conservation, 16, 66-67.

Nijman, V. 1997a Geographical variation in pelage characteristics in Presbytis comata (Desmarest, 1822) (Mammalia: Primates: Cercopithecidae). Zeitschrift für Süagetier kunde, 62, 257-264.

Nijman, V. 1997b. On the occurrence and distribution of Presbytis comata (Desmarest, 1822) (Mammalia: Primates: Cercopithecidea) in Java, Indonesia. Contributions to Zoology (Amsterdam), 66, 247-256. 
Nijman, V. and Sözer, R. 1995. Recent observations of the grizzled leaf monkey (Presbytis comata) and an extension of the range of the Javan gibbon (Hylobates moloch) in Central Java. Tropical Biodiversity, 3, 45-48.

Nijman, V. and Sözer, R. 1996. Konservasi Elang Jawa dan jenis-jenis burung endemik Jawa lainnya: Daerah prioritas kawasan konservasi di Jawa Tengah/Conservation of the Javan hawk-eagle and other endemic bird species on Java: Priority areas for protection in Central Java. PHPA/BirdLife International-Indonesia Programme Technical Memorandum 11.

RePPProT, 1990. The Land Resources of Indonesia: $A$ National Overview from the Regional and Physical Planning Program for Transmigration. Land Resources Department, National Institute Overseas Development Administration and Directorat Bina Program, Directorat Penyiapan Pemukiman, Departmen Transmigrasi, London and Jakarta.

Ruhiyat, Y. 1983. Socio-ecological study of Presbytis aygula in West Java. Primates, 24, 344-359.

van Steenis, C.G.G.J. 1965. Concise plant-geography of Java. In Flora of Java, Vol 2. (eds. C. A. Backer and R.C. Bakhuizen van den Brink), pp. 1-72. Noordhoff, Groningen.

van Steenis, C.G.G.J. 1972. The Mountain Flora of Java. Brill, Leiden.

van Steenis-Kruseman, M.J. 1950. Malaysian Plant Collectors and Collections being a Cyclopedia of Botanical Explorations in Malaysia and a Guide to the Concerned Literature up to the Year 1950. Fauna Malesiana I. Noordoff Kolff, Jakarta.

Sujatnika, 1992. Studi habitat Surili (Presbytis aygula Linneaus, 1758) dan pola penggunaanya di Taman
Nasional Gunung Gede-Pangrango dan kawasan hutan Haurbentes-Jasinga. Unpublished Thesis, Institut Pertanian Bogor. [In Indonesian]

Sujatnika, Jepson, P., Soehartono, T.R., Crosby, M.J., and Mardiastuti, A. 1995. Melestrarikan keanekaragaman hayati Indonesia: pendekatan Daerah Burung Endemik/Conserving Indonesian Biodiversity: The Endemic Bird Area Approach. PHPA/BirdLife International-Indonesia Programme, Jakarta.

Supriatna, J., Tilson, R., Gurmaya K.J., et al. 1994 Javan Gibbon and Javan Langur Population and Habitat Viability Analysis Report. IUCN/SSC Captive Breeding Specialist Group, Taman Safari Indonesia, Cisarua.

Weitzel, V. and Groves, C.P. 1985. The nomenclature and taxonomy of the colobine monkeys of Java. International Journal of Primatology, 6, 399-409.

Whitten, T., Soeriaatmadja, R.E. and Afiff, S. 1996. The Ecology of Java and Bali. The Ecology of Indonesia Series II, Periplus, Singapore.

Vincent Nijman, Institute of Systematics and Population Biology, Zoological Museum, University of Amsterdam, PO Box 94766, 1090 GT Amsterdam, The Netherlands.

Bas van Balen, BirdLife International Indonesia Programme, PO Box 310/Boo, Bogor 16003, Indonesia and Department of Terrestrial Ecology and Nature Conservation, Wageningen Agricultural University, Bornsesteeg 69, 6708 PD Wageningen, The Netherlands.

Received 27 January 1997

Accepted 18 August 1997 